Перспективи подальших наукових досліджень можуть бути пов'язані 3 підготовкою перекладачів 3 урахуванням семантико-стилістичних особливостей перекладу в конкретних сферах їхньої професійної діяльності.

\title{
Література
}

1. Збірник текстів до вивчення української лексики за професійним спрямуванням (для студентів денної та заочної форм навчання). - Краматорськ : ДДМА, 2005. - 260 с. 2. Семенчук Ю. О. Опрацювання термінологічної лексики при вивченні ділової англійської мови / Ю. О. Семенчук // Вісник КНТЕУ. - 2003. - № 5. - С. 122-128. 3. Nord Ch. Loyalty and Fidelity in Specialized Translation. CONFLUÊNCIAS - Revista de Tradução Científica e Técnica, N. ${ }^{\text {4, Maio }} 2006$ : C. 29-41. 4. Pym A. Redefining Translation Competence in an Electronic Age // Defense of a Minimalist Approach. - 2003. - Meta, 48(4). - P. 481-497. - Available at: http://www.erudit.org/revue/meta/2003/v48/n4/008533 ar.pdf. 5. Robinson D. Becoming a Translator: An Accelerated Course. London \& New York: Routledge, 2007. - P. 307.

УДК 37.012.4:372.882

Леся Басюк

\section{ГЕНДЕРНИЙ СКЛАДНИК ЗМІСТУ ШКІЛЬНИХ ПІДРУЧНИКІВ 3 УКРАЇНСЬКОЇ ЛІТЕРАТУРИ ЯК УМОВА ФОРМУВАННЯ ЕГАЛІТАРНОЇ СВІДОМОСТІ ОСОБИСТОСТІ}

Басюк Л. Б. Гендерний складник змісту шкільних підручників 3 української літератури як умова формування егалітарної свідомості особистості

У статті в контексті державних перетворень відносно гендерного складника освітнього простору проаналізовано підручник з української літератури для сьомого класу загальноосвітньої школи. Актуалізовано питання гендерно-збалансованого змісту навчальної літератури, зокрема шкільного підручника, розглянуто особливості його гендерної зорієнтованості. Ураховуючи, що важливим складником формування особистості $€$ навчальна література, акцентовано увагу на вплив іiі змісту на формування егалітарної свідомості особистості.

Ключові слова: шкільний підручник, егалітарна свідомість, гендерний компонент змісту освіти.

Басюк Л. Б. Гендерная составляющая содержания школьных учебников по украинской литературе как условие формирования эгалитарного сознания личности.

В статье в контексте государственных преобразований относительно гендерной составляющей образовательного пространства проанализирован учебник по украинской литературе для седьмого класса общеобразовательной школы. Актуализирован вопрос гендерно сбалансированного содержания учебной литературы, в частности школьного учебника, рассмотрены особенности его гендерной ориентированности. Учитывая, что важной составляющей формирования личности является учебная литература, акцентировано внимание на влияние ее содержания на формирование эгалитарного сознания личности.

Ключевые слова: школьный учебник, эгалитарное сознание, гендерный компонент содержания образования.

Basyuk L. B. Gender component in the content of school textbooks on ukrainian literature as the basis for the development of egalitarian consciousness of the individual 
In the article the textbook on Ukrainian literature for the seven grade of Middle School of General Education was decomposed in the context of state reform regarding the gender constituent of educational realm. The question of gender-balanced content of the educational materials, in particular the textbooks, was actualized and the peculiarities of gender orientation were examined. Considering that literature being an important part of identity formation, the impact of its content on the development of egalitarian consciousness of the individual was emphasized.

Key words: school textbook, egalitarian consciousness, the gender component of the content of education.

На сучасному етапі розвитку України, спрямованому на міжнародний світовий простір, здійснюється реформація всіх галузей соціального життя, зокрема і важливого державного складника- освіти. У контексті європейських вимог відбувається гуманізація, демократизація освітнього процесу, зорієнтованого, перш за все, на виховання всебічно розвинутої особистості. Це суголосно з вимогою Закону України «Про освіту», метою якого є «всебічний розвиток людини як особистості й найбільшої цінності суспільства, розвиток іiі талантів, розумових і фізичних здібностей, виховання високих моральних якостей, формування громадян, здатних до свідомого суспільного вибору, збагачення на цій основі інтелектуального, творчого, культурного потенціалу народу» [2]. На нашу думку, невід'ємним складником такої особистості є іiї гендерна обізнаність, егалітарна свідомість, формування яких відбувається i у шкільному просторі під час навчання, виховання, розвитку дитини. У руслі утвердження Україною на підтримку встановлення гендерного паритету як однієї з цілей розвитку тисячоліття, проголошеної ООН, низки офіційних документів: Закон України «Про забезпечення рівних прав і можливостей жінок та чоловіків» (2005р.), Постанова «Про затвердження Державної програми 3 утвердження гендерної рівності в українському суспільстві на період до 2010 року» (2006 р.), Положення «Про Міжвідомчу раду 3 питань сім'ї, гендерної рівності, демографічного розвитку та протидії торгівлі людьми» (2007 р.) тощо. в освітньому просторі гендерне питання знайшло своє відображення в наказі (№839 від 10.09.2009) Міністерства освіти і науки України Про впровадження гендерної рівності в освіту. Відповідно до зазначеного документа навчальні матеріали повинні були пройти гендерну експертизу ще до 2010 року, через об'єктивні причини прописані у наказі заходи не були реалізовані повною мірою і питання залишається відкритим. Уважаємо, що особливої уваги щодо гендерної корекції потребує шкільний підручник, адже він $\epsilon$ важливим інструментом у навчанні. У ньому, окрім знань з певного предмета, закодовано матрицю світу, моделі поведінки, які школярство перебирає на власне життя. I від того, яким буде зміст підручника, залежить сформований у підлітків гендерний характер світу.

За влучним зауваженням педагога С. Сірополка, художня література «дає ученикові образи і малюнки, уяви і розуміння щодо щоденних взаємин людей, пробуджує, поширює й ушляхетнює уяву і почуття, виховує визнання того, що в цих взаємозв'язках відтворює прекрасне і потворне, моральне і аморальне, закидає в душу його ідеальні поривання» $[4$, с. 159]. Свою увагу ми зосереджуємо на підручнику 3 української літератури, оскільки художні образи є носіями моральних цінностей, а художній твір, віддзеркалюючи світ крізь призму авторського бачення, акумулює в собі людське буття, знання минулого, яке трансформується у сучасне і проектує майбутнє.

Гендерний складник навчальних матеріалів входить до кола наукових інтересів таких дослідників та дослідниць, як: І. Гуцуляк, Т. Дороніна, О. Кікінежді, Н. Коніщева, Л. Мозгова, I. Мунтян, О. Остапчук, Н. Шевченко, О. Цокур, О. Ярська-Смірнова. 
Об’єктами їх робіт стали гендерна педагогіка, теоретико-методологічні основи гендерної освіти і виховання учнівської молоді; гендерна освіта в соціогуманітарному просторі; гендерний складник методики навчання української літератури; гендерні стереотипи у виданнях для дошкільнят тощо.

Шкільний підручник у контексті гендерної корекції досліджували такі науковці: C. Вихор, Т. Говорун, Г. Жирська, О. Кобельська, О. Луценко, О. Марущенко, О. Слюсар та ін.

Гендерний дискурс у науково-педагогічній спадщині свідчить про нагальність та актуальність обраного напряму дослідження.

Попри неабиякий інтерес 3-поміж науковців до проблеми гендерного складника в освітніх матеріалах, зокрема шкільному підручнику, констатуємо велику кількість лакун - не завжди чітким є розуміння сутності понять «гендер», «ґендерна асиметрія», «ґендерний баланс» тощо, унаслідок чого переважає поверхове ставлення до окресленої проблеми i незнаходження шляхів іï розв'язання, нестача та відсутність чітко визначених критеріїв, за якими повинна проводитись гендерна експертиза навчальних матеріалів і власне державних практичних дій у цьому напрямі.

Метою статті є висвітлення особливостей змісту сучасного підручника 3 української літератури в ракурсі формування егалітарної свідомості підлітків.

До основних завдань віднесено такі: проаналізувати чинний підручник 3 української літератури (через обмеженість даної статті - лише один); встановити вплив його змісту на формування свідомості особистості.

Егалітарна свідомість особистості неможлива без прищеплення людині гендерної культури. Гендерна культура це - «система історично сформованих, відносно стійких установок, переконань, уявлень, моделей поведінки, що втілюють досвід попередніх поколінь людей, виявляються в діяльності суб'єктів соціально-культурного процесу та забезпечують відтворення гендерного життя суспільства на основі наступності» [1, c. 264]. Запорукою гендерного виховання, на нашу думку, є обов'язкове впровадження в освіту гендерного підходу, мета якого - «створення умов для гендерної соціалізації школярів, що сприяють вихованню міжстатевих відносин, вільних від жорстких стереотипів маскулінності та фемінності у традиційному розумінні, що може стати запорукою виховання нової особистості 3 високими інтенціями відкритості та адаптивності в усіх галузях життя, необмеженими можливостями індивідуального життєвого вибору й самореалізації» [5, с. 24] У підручнику, який відіграє вагому роль у вихованні особистості, гендерний компонент може виявлятися на різних рівнях:

- лінгвістичне поле підручника, звертання до читацької аудиторії;

- ілюстративний матеріал: обкладинка, фотокартки, репродукції картин, малюнки, що супроводжують мовне полотно книги;

- художні твори, подані для вивчення у класі, у яких нерідко відбито гендерні стереотипи суспільства;

- допоміжні матеріали - крилаті вислови, тести для перевірки вивченого, рубрики для кращого запам'ятовування, цитати відомих людей тощо.

Задля аналізу ми взяли підручник з української літератури для 7 класу [3]. Обкладинка підручника $є$ гендернозбалансованою, на ній зображено парубків та дівчат в українських народних костюмах.

3-поміж 16 постатей митців, твори яких вивчаються на уроці, лише 2 авторки (Ліна Костенко та Любов Пономаренко), що у відсотковому співвідношенні становить 87\% до $13 \%$. Це створює хибне уявлення про роль жінок у розвитку української літератури й підкріплює стереотип про те, що мистецтво, зокрема література, $\epsilon$ прерогативою чоловічої статі. 
Мовне поле підручника має як гендернонейтральні форми звертань до аудиторії, так і андроцентричні (домінування чоловічого). Здебільшого у книзі використовуються форми дійсного та наказового способу дієслів II особи множини: «прочитайте», «як ви уявляєте собі», «підтвердіть свою відповідь», «спробуйте створити», «ви знаєте», «підготуйте» тощо, що охоплюють усіх реципієнтів. Проте нерідко мовлення йде виключно про чоловічу стать: «Дорогі семикласники» [3, с. 9], «Любі семикласники» [3, c. 79], «Життя літературного твору можливе лише на основі гармонії автора і читача» [3, c. 11], «без читача літературний твір гине» [3, с. 13], «влаштуйте цікавий літературний вечір, на якому кожен бажаючий зможе виступити» [3, с. 13], «перед читачем постають» [3, с. 52], «той, хто досягне вершини піраміди знань, буде пошанований званням «Ерудит» [3, с. 9] тощо. За такого спілкування 3 аудиторією поза увагою залишається іiї жіноча частина, імпліцитно налаштовуючись на пасивність. Бачимо, що навіть коли можливе використання форми множини - кожні бажаючі, хто досягнуть, будуть пошановані тощо - традиційно обирається граматична категорія чоловічого роду. Те ж стосується випадків, коли йдеться про професії, національність, види діяльності. Наприклад, назва розділу підручника «Ми - українці», хоча читачки, звичайно, є українками. У пояснювальних матеріалах читаємо: «не завжди українці мали право на незалежність та власну мову» [3, с. 56], між тим і українки такого права не мали. У вступному слові бачимо: «цого року ви маєте чудову нагоду продовжити мандрівку сюжетними лабіринтами найкращих творів українських письменників» [3, с. 9], «ви зможете ознайомитися 3 біографіями письменників» [3, с. 9]. Лексема «письменник» використовується й тоді, коли йдеться і про жіночу постать: «Багато українських письменників, із творами яких ви вже ознайомлені, зокрема Леся Українка, були вдячні Іванові Яковичу за допомогу й підтримку» [3, с. 37].

Цікавим $є$ момент, коли йдеться про вчительську професію. Відомо, що частіше у школі викладають, особливо гуманітарні дисципліни, жінки, тобто вчительки. Проте читаємо у завданні про заохочення учнівства: «учитель може «присудити» вам від 4-х до 6-ти балів» [3, с. 9]. Навіть коли, скоріш за все, перед класом стоїть учителька, їі називають учителем. Розуміємо, що це певне кліше - використання лексеми чоловічого роду на позначення професії чи виду діяльності, але, вважаємо, що настав час його змінювати.

Вияви мовного андроцентризму спостерігаємо і в завданнях до творів, наприклад, під час аналізу повісті М. Стельмаха «Гуси-лебеді летять...» пропонується знайти «у домашніх чи бібліотечних мистецьких альбомах картини видатних українських художників» [3, с. 121], тим самим позбавляючи дітей вибору звернутись до мистецьких робіт українських художниць. До повісті І. Франка «Захар Беркут» учнівству запропоновано зняти рімейк однойменного фільму, пригадавши «відомих українських акторів і визначитись, хто саме з них зможе виконати ролі Захара, Мирослави, Максима, Тугара, Пети та ін.» [3, с. 55]. Виходячи 3 цього завдання, роль Мирослави має виконувати актор-чоловік, що, видається дещо абсурдним. Узагальнення до чоловічої статі спостерігаємо і в іншому коментарі до зазначеного твору, коли йдеться про Мирославу та Максима: «Саме вони, ці двоє самовідданих, волелюбних героїв, символізують високі ідеали єдності» [3, с. 51]. Безперечно, Мирослава - героїня, але тут також спрацьовує стереотипне кліше, насичення тексту якими поступово призводить до укорінення гендерного стереотипу про пасивність жіночої статі. Привертає увагу і гендерна маркованість образів. Якщо у попередньому прикладі Мирославі з Максимом надавалась спільна характеристика, то в іншому читаємо: «ще кілька занять і завдань - i ви попрощаєтесь із красунею Мирославою i відважним Максимом» [3, с. 53]. 
Характеристика образів відтворює маскулінні та фемінні ознаки: чоловік - відважний, мужній, сильний, а жінка - красива, гарна, приваблива.

Безпосередньо наратив творів ми не аналізували, ураховуючи, що їх добір до навчальної програми відбувався згідно з Концепцією літературної освіти, спираючись на виховний потенціал художнього слова. Проте звернули увагу на яскравих персонажів, обговоренню яких приділяється чимала увага після прочитання творів: Максим і Мирослава «Захар Беркут», Павлусь «За сестрою», Михайлик «Гуси-лебеді летять...», Клим «Климко», Павлусь «Скарб», хлопчик «Цвіт щастя», Планетник «Планетник», Юрко і Тося «Сім’я дикої качки», Фрідріх «Гер переможений», Толик та Сергійко «Блакитна дитина». Переважна більшість- чоловіки. Пригадавши вище сказане, складається хибне враження про те, що українська література написана чоловіками про чоловіків і для чоловіків.

Безумовно, ми розуміємо, що це не $\epsilon$ відображенням світогляду авторки підручника, вона лише транслює гендерний устрій сьогодення. I саме для його зміни, для виховання покоління із іншим світосприйняттям потрібна гендерна експертиза підручників, введення до їх змісту гендерної компоненти.

Аналіз змісту підручника засвідчив наявні в ньому гендерний дисбаланс, вияви андроцентризму, гендерні стереотипи, використання лексичних кліше - обирання чоловічого роду на позначення як чоловіків, так і жінок. Усе це у поєднанні із вчительським словом має неабиякий вплив на формування особистості підлітків. Хлопці і дівчата можуть засвоїти певні ролі за статтю (наприклад, у дівчат може сформуватись відчуття своєї меншовартості, другорядності), які обмежуватимуть їх виояви бажання, розвиток, що суперечить концепту егалітарності.

Отже, потребою сучасної освіти є перегляд принципів укладання підручників. Уважаємо, що повинна враховуватись, окрім дидактичних, психологічних, методичних принципів, гендерний складник матеріалів, вивчаючи які учнівство вибудовує самоідентифікацію, взаємозв'язки із світом, соціумом. I щоб ці відносини були гармонійними, обов'язковою умовою є гендерна чутливість вчительського складу та гендерно-збалансований зміст підручника, що сприятиме вихованню егалітарної свідомості особистості.

Безперечно, ми лише окреслили проблему і запропонували шлях іiі розв’язання, який вимагає залучення до нього усіх ланок освітнього процесу. Проте саме концептуальна перебудова засад укладання шкільних підручників, урахування не тільки на законодавчому папері, а й на практиці гендерного компонента уможливлять досягнення очікуваного результату - виховання вільної у своєму виборі, позбавленої штучної обмеженості за статтю особистості з егалітарною свідомістю, до чого й повинна йти держава, що дотримується демократичних принципів, якою і прагне бути Україна.

\section{Література}

1. Дороніна Т. О. Теоретико-методологічні засади гендерної освіти та виховання учнівської молоді: монографія / Тетяна Олексіївна Дороніна; НАПН, Інститут вищої освіти, КДПУ, МОНМС України. - Кривий Ріг: Видавничий дім, 2011. - 331с. 2. Закон України про освіту [Электронный ресурс].- Режим доступу: http://zakon2.rada.gov.ua/laws/show/1060-12. 3. Міщенко О. I. Українська література. [підруч. для 7 класу загальноосвіт. навч. закл.]. / О. І. Міщенко. - К. : Генеза, 2007 288 с. 4. Сірополко С. О. Завдання нової школи / С. О. Сірополко // Маловідомі першоджерела української педагогіки (друга половина XIX- XX ст.) : хрестоматія/ 
упоряд. : Л. Л. Березівська та ін. - К. : Наук. світ, 2003. - С. 156-163. 4. Старовойтова Ж. А. Организация процесса обучения в основной школе на основе гендерного подхода : дис. на здобуття наук. ступеня канд. пед. наук : спец. : 13.00.01 «Общая педагогика, история педагогики и образования» / Ж. А. Старовойтова. - Омск, 2007. - 204 с.

\section{ЄВРОПЕЙСЬКІ ОСВІТНІ СТАНДАРТИ ЯК ОРІЕНТИР ІНШОМОВНОЇ ОСВІТИ В УКРАЇНI}

Гаманюк В. А. Свропейські освітні стандарти як орієнтир іншомовної освіти в Україні.

У статті досліджується проблема впровадження європейських освітніх стандартів у галузі іншомовного навчання в системі вищої немовної освіти в Україні. Аналізуються рамкові програми з англійської та німецької мов для професійного спілкування 3 огляду на соціокультурний компонент та орієнтацію на автономне навчання.

Ключові слова: рамкова програма, соціокультурна компетенція, іншомовна комунікативна компетенція, автономне навчання.

Гаманюк В. А.Европейские стандарты образования как ориентир иноязычного образования в Украине.

В статье исследуются вопросы имплементации европейских стандартов в сфере иноязычного образования в системе высшего неязыкового образования в Украине. Анализируются рамочные программы по английскому и немецкому языку для профессионального общения с точки зрения включения социокультурного компонента и ориентации на автономное обучение.

Ключевые слова: рамочная программа, социокультурна компетенция, иноязычная коммуникативная компетенция, автономное обучение.

Hamanyuk V. A. European Educational Standards as a Reference Point of Foreign Language Education in Ukraine.

The article deals with the question of implementation of European educational standards to the Ukrainian system of foreign language high education. The frame programs for English and German for professional communication (integration of multicultural components and autonomic learning aspects) are analyzed.

Key words: frame program, multicultural competence, foreign language communicative competence, autonomic learning.

Україна прагне входження до загальноєвропейського освітнього простору, передумовою чого є адаптація державної системи освіти до європейських вимог. В іншомовній освіті зміни відбуваються на рівні визначення змісту та рамкових умов навчання і вивчення іноземних мов. Базовим документом у галузі іншомовного навчання $\epsilon$ Загальноєвропейські рекомендації з мовної освіти, розроблені колективом авторів із різних країн, які були видані у 2000 р. У 2001р з'явилися українською мовою і 3 того часу є основою для розроблення рамкових програм з іноземних мов, навчальних планів та екзаменаційних матеріалів.

У вітчизняному науковому просторі питанням європейського виміру в освіті, вивчення діяльності Ради Свропи, іiі внеску у зближення народів Свропи, прагнення 